\title{
Effects of EVFTA on Vietnam's apparel exports: An application of WITS-SMART simulation model
}

\author{
VO THANH THU ${ }^{a}$, LE QUYNH HOA ${ }^{b}$, HOANG THU HANG ${ }^{c}$ \\ ${ }^{a, c}$ University of Economics Ho Chi Minh City \\ ${ }^{b}$ Thu Dau Mot University
}

\begin{abstract}
A R T I C L E I N F O
A B S T R A C T

Received: 16 Sep, 2016

Revised: 28 Oct, 2016

Accepted: 2 Oct, 2018

Available online

The textile and apparel industries play an important role in Vietnam's economy in general and the manufacturing sector in particular. As a matter of fact, Vietnam ranks as one of the leading suppliers of textile and apparel for major economies in the world, including the European Union. This paper attempts to examine the potential impacts of the European Union - Vietnam Free Trade Agreement on the export of Vietnam's apparel at three levels: 2 , 4, 6-digit HS respectively, assuming full liberalization from Vietnam to European Union by 2026. An analysis is undertaken using WITS-SMART

JEL classification:

J21, M12, M41 model to identify the variation of Vietnam's apparel export as well as to predict some most affected products if European Union - Vietnam Free Trade Agreement is in full application. As a result, Vietnam's apparel exporting to European Union will increase significantly by $42 \%$ compared to

\section{Keywords} the base year (2016) and is expected to reach US $\$ 4.220$ billion in the next 8 WITS-SMART model; EVFTA; Textile; Apparel; Export. years. Due to trade diversion dominates over trade creation effect, Vietnam's apparels will get more gains than non - European Union - Vietnam Free Trade Agreement members; however, this result is not because of an effective allocation of resources. Therefore, policy makers should implement some remedies to improve the competitive of Vietnam's apparels, to reduce the production price to bring advantages for both Vietnam and Europe.
\end{abstract}

\footnotetext{
a vothanhthu@ueh.edu.vn, * Corresponding author.

b hoalq@tdmu.edu.vn

changht@ueh.edu.vn

Please cite this article as: Vo, T. T., Le, Q. H., \& Hoang, T. H. (2018). Effects of EVFTA on Vietnam's apparel exports: An application of WITS-SMART simulation model. Journal of Asian Business and Economic Studies, 25(S02), 04-28.
} 


\section{Introduction}

The liberalization of international trade has contributed in a major way to the rapid economic growth of the international economy and altered the competitive dynamics of nations, firms, and industries. In the case of the textile and apparel (T\&A) industries, apparel is one of the oldest and largest export industries in the world. Globally, Vietnam was the world's third largest apparel exporter in 2015, after China and Bangladesh (WTO, 2016). In 2015, Vietnam's textile and clothing exports totaled $\$ 28$ billion ( $84 \%$ were clothing), which represented $16 \%$ of Vietnam's total merchandise exports. EU is the second largest market for textile and apparel of Vietnam with a share of 16 per cent in 2015. Specifically, Vietnam and EU have engaged in a free trade agreement (FTA) which will change the prices of imports from partners due to reduction or phasing of tariffs starting from 2018. This FTA will inevitably involve some "trade creation" effects by allowing cheaper products from other member states to substitute for more expensive domestic production or "trade diversion" effects by substituting intra-bloc imports for imports from outside the group that were cheaper when both faced equal tariffs (Schiff \& Winters, 2003).

In view of EU-Vietnam free trade agreement (EVFTA) full engagement, this paper attempts to examine potential impacts of EVFTA on Vietnam's apparel exporting to the EU and to compare various hypothetical tariff liberalization scenarios on certain key variables, such as prices, imports, exports and revenue using SMART models. All export and import trade data used in this study was sourced primarily from credible online SMART database and Trade Map data flow, the Office of Textiles and Apparel, International Trade Administration... and so on. Thus, this study will add to the existing literature on this issue.

Since the introduction of the paper has been given, the next section gives a brief overview impact of FTAs, apparel industry of the world and Vietnam and EVFTA, followed by the third section presenting the analytical framework, including WITS-SMART model, data and robustness test. Section 4 offers the results and discussion. Lastly, section 5 summarizes the findings of the paper and policy implications.

\section{Background}

\subsection{Impacts of FTAs on trade}

Since the Doha development round of the WTO, the merits of free-trade agreements (FTAs) have had a controversial topic of many economists. Some argue that the tremendous number of FTAs have been hampered the domestic production and non-FTA members by eliminating tariff between partners (Levy, 1997), while others view FTAs as a positive vehicle to move nations toward free multilateral trade (Freund, 2000).

By creating a more integrated trading area, FTAs eliminate trade barriers on goods between member nations. Thus, the agreement increases trade volume among the member 
countries through trade creation and diversion effects. The earliest work on the theory of trade creation and trade diversion was presented by Viner (1950).

Trade creation occurs when FTAs reduce the import prices from partners and change the patterns of domestic demand. This is achieved through facilitation of consumer choices and increasing competition between foreign manufacturers and local producers. In this case, the price of the imported goods after the tariff change become lower, which results in an increasing level of domestic demand for imports from a specific trading partner. Indeed, the benefits of tariff changes would be passed on to consumers. This brings about a better allocation of resources (Laird \& Yeats, 1986).

The trade diversion effect can be explained by the fact that imports of goods from a member are going to further increase due to the substitution away from imports of goods from other countries that becomes relatively more expensive. It means the trade flow is diverted from a truly cost-efficient partner to less efficient one, because when a country joins in a member of economic union, which makes its goods cheaper within a union, but higher compared to the rest of the world. This leads to ineffective allocation of resources (Laird \& Yeats, 1986; Othieno \& Shinyekwa, 2011).

According to current literature research, the impacts of FTAs on textile and apparel's trade creation and trade diversion vary and depend on the organizational structure of the association (Krueger, 1999). For example, Tsang and Au (2008) assessed and divulged the impacts of North American Free Trade Agreement (NAFTA) on textile and clothing exports from selected South and Southeast Asian developing countries. The study found that textile and apparel exports from the South and Southeast Asian developing countries to the US market were hampered by the enforcement of NAFTA in the 1990s due to the trade diversion effect. By contrast, Datta and Kouliavtsev (2009) examined the impact of US textile imports before and after the creation of NAFTA. They claimed that there was little evidence of trade diversion in textiles frequently attributed to NAFTA, while trade creation was clearly present.

Gurler et al. (2006) investigated the effects of FTA on intra-industrial trade with a case study of textile sector in Turkey. The results showed that agreements had a positive effect on textile import of Turkey. By the rise of intra-industrial trade, while taking advantage of various markets in textile sector, Turkey will be able to offer a wide variety of products to customer, and will be able to reap economies of scale.

As for Vietnam, there is a very limited number of papers evaluating how particular FTAs would have affected Vietnamese textile and apparel exports. Knowingly, the study of Sayres (2002) with the focus on Vietnam's textile and apparel indicated that the export of textile products was expected to be increasing remarkably after the United States and Vietnam signed Bilateral Trade Agreement (BTA). In addition, Baker et al. (2014) estimated the impact of EVFTA on Vietnamese economy and forecasted that textile and apparel trade would be one of the most beneficial sectors as EVFTA comes into force. 


\subsection{Apparel industry overview}

Known to date, textile and apparel manufacturing process begins with fiber, and passes through four main stages of processing: yarn, fabric, finishing and fabrication (Platzer, 2012). This paper focuses on the last process of fabrication and final products which are articles of apparel and clothing accessories, knitted or crocheted; and not knitted or crocheted, which belong to HS groups of Chapter 61 and 62 (Appendix A). These groups of products usually cover nearly $50 \%$ and $80 \%$ of all T\&A exports of the world and Vietnam respectively.

Vietnam does have a growing textile industry, but currently the majority of its yarns and fabrics are sourced regionally, from China and other Asian suppliers such as South Korea and Taiwan. Only about $12 \%-13 \%$ of fabrics and other input materials are sourced from local textile manufacturers (GSO, 2016). A majority of big textile and garment manufacturers in Vietnam are based in Japan, Hong Kong, South Korea, Taiwan, Austria, and Australia, all these counries also consider expanding their current production in Vietnam.

Table 1 below shows the market share (\%) of apparel by nations from 2007 to 2015 . As can be seen from this table, because of high consumers' purchasing power (often measured by GDP per capita) and size of the population, the EU nations, the United States and Japan became the top three importers of world apparel. Altogether, they accounted for over twothirds of world imports, but this number decreases from 77 percent in 2007 to 69 percent in 2015. This downward trend indicates that import demand from other economies, especially some emerging markets (Hongkong, Canada, South Korea), have been growing faster over the past decade.

Table 1.

Top World Apparel Importers by share

\begin{tabular}{lccccccccc}
\hline $\begin{array}{l}\text { Main } \\
\text { Buyers }\end{array}$ & 2007 & 2008 & 2009 & 2010 & 2011 & 2012 & 2013 & 2014 & 2015 \\
\hline EU & $45.80 \%$ & $47.20 \%$ & $47.90 \%$ & $45.50 \%$ & $45.50 \%$ & $41.80 \%$ & $42.10 \%$ & $43.70 \%$ & $40.80 \%$ \\
USA & $24.10 \%$ & $21.80 \%$ & $21.20 \%$ & $22.10 \%$ & $20.70 \%$ & $21.60 \%$ & $21.30 \%$ & $20.70 \%$ & $21.90 \%$ \\
Japan & $6.90 \%$ & $6.90 \%$ & $7.60 \%$ & $7.40 \%$ & $7.90 \%$ & $8.60 \%$ & $8.10 \%$ & $7.10 \%$ & $6.60 \%$ \\
Hong & $5.50 \%$ & $5.00 \%$ & $4.70 \%$ & $4.60 \%$ & $4.10 \%$ & $4.10 \%$ & $3.90 \%$ & $3.60 \%$ & $3.40 \%$ \\
Kong & & & & & & & & & \\
Canada & $2.10 \%$ & $2.10 \%$ & $2.20 \%$ & $2.20 \%$ & $2.20 \%$ & $2.30 \%$ & $2.30 \%$ & $2.20 \%$ & $2.20 \%$ \\
Korea & $1.20 \%$ & $1.10 \%$ & $1.00 \%$ & $1.20 \%$ & $1.50 \%$ & $1.60 \%$ & $1.80 \%$ & $1.90 \%$ & $2.00 \%$ \\
\hline
\end{tabular}

Source: Author's calculation from ITC (2016), Apparel represented by HS 61, 62.

In terms of global suppliers (see Table 2), most of apparel manufacturers are located in developing countries such as China, India, Bangladesh, and Vietnam. With rich natural resources and labor costs significantly lower than other competitors in developed nations, these top three producers accounted for over a half of world textile and apparel with $52.4 \%$ 
in 2015. Specifically, China was the leading supplier by far in the global apparel export share during the past 8 years with the average share of $40 \%$, kept far ahead of the following ones such as Bangladesh, India and Vietnam.

Table 2.

Top global apparel suppliers by share

\begin{tabular}{lcccccccc}
\hline Suppliers & 2008 & 2009 & 2010 & 2011 & 2012 & 2013 & 2014 & 2015 \\
\hline China & $38.70 \%$ & $38.70 \%$ & $41.40 \%$ & $40.80 \%$ & $41.50 \%$ & $41.50 \%$ & $40.80 \%$ & $40.30 \%$ \\
Bangladesh & $3.30 \%$ & $3.90 \%$ & $4.30 \%$ & $4.70 \%$ & $5.70 \%$ & $6.00 \%$ & $6.20 \%$ & $6.80 \%$ \\
Vietnam & $2.40 \%$ & $2.60 \%$ & $2.90 \%$ & $3.10 \%$ & $3.40 \%$ & $3.70 \%$ & $4.20 \%$ & $5.30 \%$ \\
India & $2.80 \%$ & $3.60 \%$ & $3.00 \%$ & $3.40 \%$ & $3.20 \%$ & $3.50 \%$ & $3.50 \%$ & $3.80 \%$ \\
Turkey & $3.60 \%$ & $3.60 \%$ & $3.60 \%$ & $3.30 \%$ & $3.40 \%$ & $3.30 \%$ & $3.40 \%$ & $3.30 \%$ \\
Indonesia & $1.70 \%$ & $1.80 \%$ & $1.90 \%$ & $1.90 \%$ & $1.80 \%$ & $1.70 \%$ & $1.60 \%$ & $1.60 \%$ \\
Cambodia & $0.80 \%$ & $0.80 \%$ & $0.90 \%$ & $1.00 \%$ & $1.00 \%$ & $1.10 \%$ & $1.10 \%$ & $1.30 \%$ \\
Mexico & $1.30 \%$ & $1.30 \%$ & $1.20 \%$ & $1.10 \%$ & $1.10 \%$ & $1.00 \%$ & $0.90 \%$ & $1.00 \%$ \\
Sri Lanka & $0.90 \%$ & $1.00 \%$ & $1.00 \%$ & $1.00 \%$ & $0.90 \%$ & $1.00 \%$ & $1.00 \%$ & $1.00 \%$ \\
Pakistan & $0.90 \%$ & $0.90 \%$ & $1.00 \%$ & $1.00 \%$ & $0.90 \%$ & $0.90 \%$ & $0.90 \%$ & $1.00 \%$ \\
Total & $56 \%$ & $57 \%$ & $57 \%$ & $58 \%$ & $61 \%$ & $61 \%$ & $63 \%$ & $64 \%$ \\
\hline
\end{tabular}

Source: Author's calculation from ITC (2016), Apparel represented by HS 61, 62

\subsection{Overview of Vietnam's apparel export}

In Vietnam, textile and apparel manufacturing is one of the largest economic sectors, consisting 4,000 enterprises with a turnover of US\$20 billion a year, accounting for $15 \%$ of GDP (VITAS, 2016). In 2015, Vietnamese apparel products are exported to over 180 countries and territories in the world with total exports of US\$21.4 billion.

Beside the US market, Europe is a promising market for Vietnamese apparel with export turnover reaching US\$3.4 billion in 2015, accounting for 16\% of Vietnamese apparel export (Figure 1). The textile exporting to EU has been witnessing a steady growth over the recent years and pushing Vietnam to become one of the top T\&A exporters to EU. 


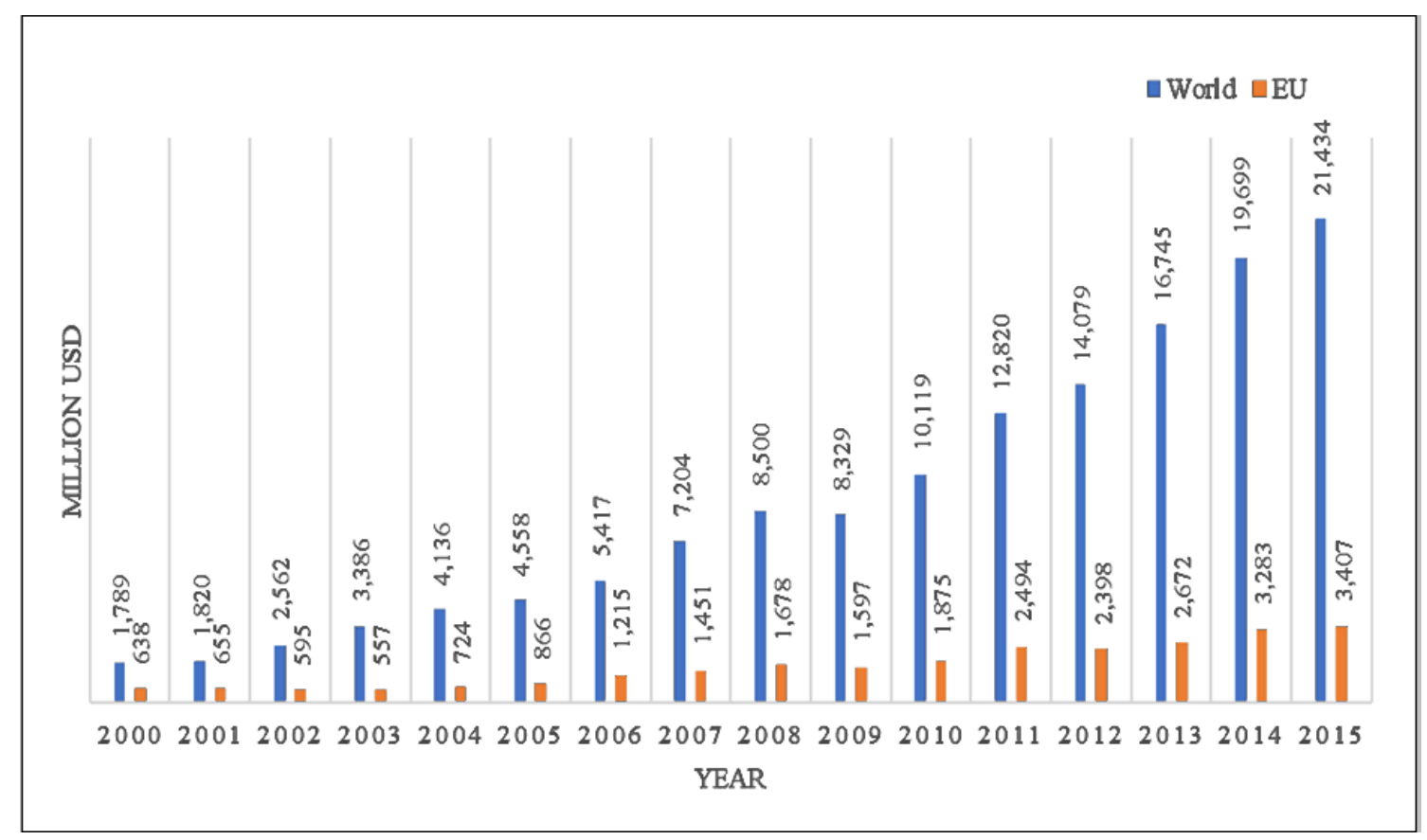

Figure 1. Vietnam's apparel exports to the World and EU (US\$ Million)

Source: Author's calculation from UN Comtrade, Apparel represented by HS 61, 62

More interestingly, EU and Vietnam have started the negotiation for FTA since June 2012. At that time, EU, covering a big market with 28 partners, has been granting Vietnam with the Generalized Scheme of Preferences (GSP).

The EU-Vietnam free trade agreement is expected to substantially expand Vietnam's textile and apparel exports to the EU market. In other words, EU's import duties on textile and apparel from Vietnam will be eliminated through an eight-year phase-out period once the agreement comes into force.

EVFTA has planned the elimination of roughly 99\% of all tariff lines. Vietnam will liberalize tariffs over a 10-year period and the EU over an 8-year period. EU duties on textile apparel have periods from five to eight years for the more sensitive items and three years and entry into force for less sensitive goods. The agreement also covers non-tariff barriers to trade and other trade related aspects such as public procurement, regulatory issues, competition, services, investment, intellectual property rights, and sustainable development (MOIT, 2016).

According to Vietnam's tariff schedule, apparel reductions are categorized into four groups: A, B3, B5, B7 with the basic tariff rate of the negotiated year 2012. Accordingly, 43\% of apparel tariff lines are under Schedule A, where tariff rates shall be eliminated immediately on the date the EVFTA officially applies (see Figure 2). 


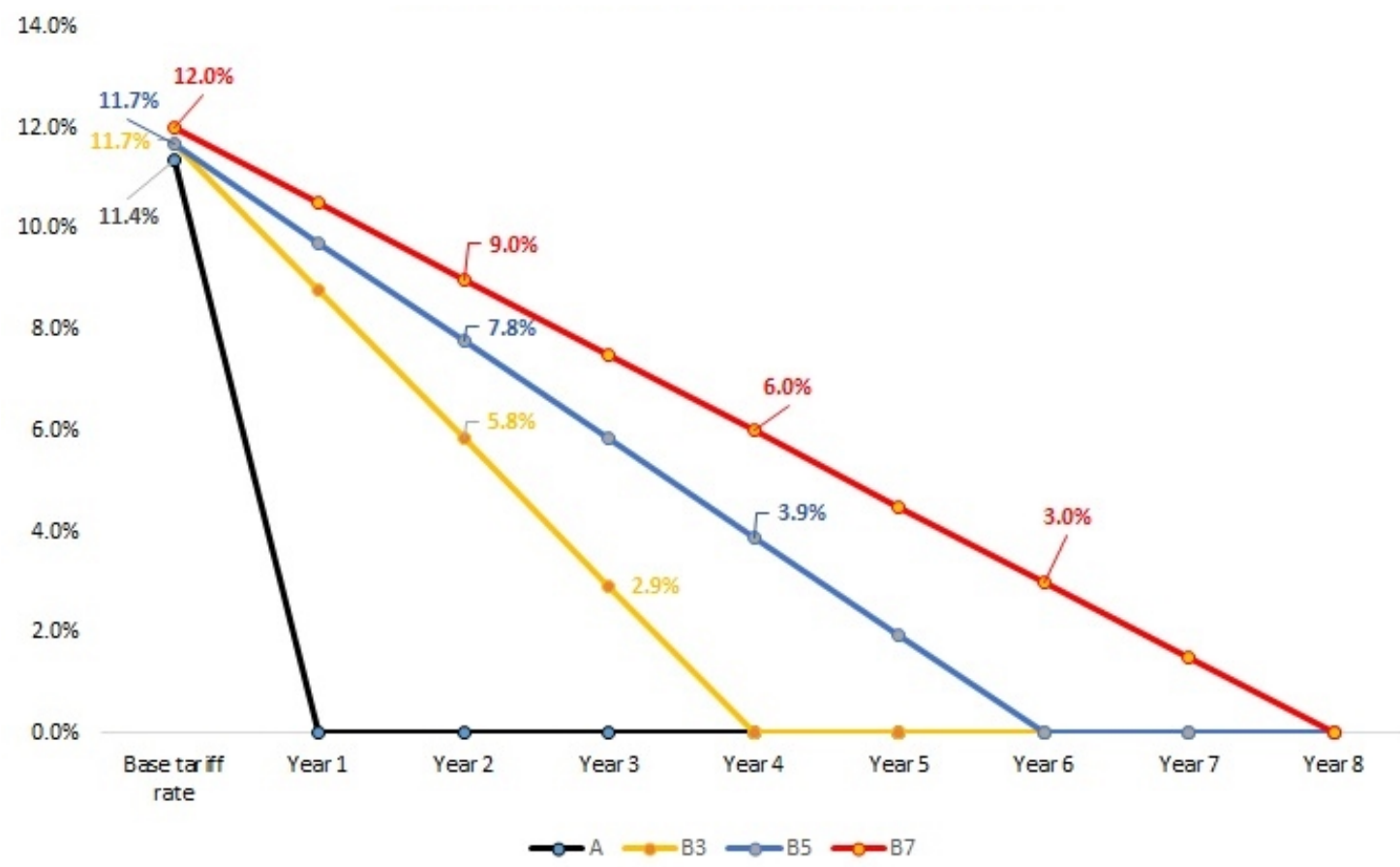

Figure 2. Tariff Phase-out Details for Vietnam's apparel to EU market by EVFTA

\begin{tabular}{ll}
\hline Category & Tariff Phaseout Details \\
\hline A & $\begin{array}{l}\text { be free of any customs duty on the date the Agreement comes into force (EIF), expected } \\
\text { in } 2018\end{array}$ \\
B3 & removed in four equal annual stages since effective date, expected in 2022 \\
B5 & removed in six equal annual stages since effective date, expected in 2024 \\
B7 & removed in eight equal annual stages since effective date, expected in 2026 \\
\hline
\end{tabular}

Source: Vietnamese WTO Center. (2017). EU-Vietnam Free Trade Agreement: Agreed text as of January 2016

Additionally, given rules of origin, Vietnam may benefit from EU textile producers with fabrics originating in the EU and some types of extended accumulation with South Korean fabrics after complying with certain administrative requirements. In the future, Vietnamese exporters may be able to move from certificates of origin issued by government to selfcertification to the EU whenever Vietnamese exporters are ready to do so. 


\section{Analytical framework}

\subsection{Model framework}

\section{WITS-SMART model}

Many studies have used different analysis models to estimate the impacts of FTAs on trade. As for equilibrium models, a partial-equilibrium (PE) or general-equilibrium (GE) model can be chosen with its own advantages and disadvantages. Partial equilibrium models are well-suited for analysis focusing on a specific sector, while general equilibrium models are more suitable for estimating the second focus (Mikic, 2005). Some partial equilibrium models have been developed to simulate international trade policy changes, including SMART, GSIM, ATPSM, SWOPSIM, etc.

WITS-SMART model is the partial equilibrium approach developed by the World Bank and UNCTAD. It can calculate trade creation, trade diversion, welfare effects of a tariff change for a single product to enable better implications for governments and enterprises (Amjadi et al., 2011). Many scientists have spent a great deal of efforts to investigate theoretical models that would map into the WITS-SMART Simulation, including Veeramani and Saini (2010), Othieno and Shinyekwa (2011), Vu (2016), Nguyen (2015), Cassing et al.(2010), Baker et al. (2014).

Veeramani and Saini (2010) used PE modeling approach (SMART model and gravity model) to assess the impact of the Asian-India Free Trade Area (AIFTA) on agricultural commodities and suggested that this agreement would lead to an increasing trade creation in such imports by India and new imports may have adverse impact for the livelihood of the Indian farmers engaged in the production of these commodities. Othieno and Shinyekwa (2011) used the WITS-SMART simulation model to improve the effects of the East African Community Customs Union on Uganda to trade, welfare and revenue effects since 2005.

In Vietnam, $\mathrm{Vu}$ (2016) adopted the WITS-SMART model to foresee the impact of tariff liberalization under EVFTA on Vietnam's pharmaceutical imports. In the MUTRAP project, Cassing et al. (2010) applied this model to analyze the potential effects of FTAs on Vietnamese economy by evaluating some indicators such as trade creation, trade diversion, revenue effect, welfare effect, export and import effect. The study of "Assessing the longterm impacts of EU-Vietnam FTA" by Baker et al. (2014) applied both the SMART and CGE model to estimate how EVFTA would affects Vietnam's trade by 2025 and found out that textiles, apparels and agricultural products would get the most advantages from tariff elimination under the EVFTA.

We adopted the PE simulation model to identify the change of Vietnam's apparel exports and to identify the most affected products by EVFTA which comes into force in early 2018. This model is suitable for the purposes of this study.

First, PE model allows an analysis at a fairly disaggregated (or detailed) level, even at 6digit HS level. As the negotiations of recent free trade agreements are conducted at a very 
disaggregated level, the PE may be more appropriate and accurate than the framework of a general equilibrium models. Secondly, PE models require minimal data such as some parameters of elasticity and data for the tariff applied in new trade policy, which is timely and able to capture short- and medium-term effects. Thirdly, their results are relatively straightforward to interpret, since only a relatively limited number of equations are used to calculate changes in demand and supply (Amjadi et al., 2011).

One of PE approach is Single Market Partial Equilibrium Modelling Tool (SMART) developed by the World Bank. The model can calculate the effect of trade policy changes on tariff revenue, consumer surplus. It is also a simple means of measuring trade creation, trade diversion, welfare effects of a tariff change for a single product. One main drawback with the online version of the SMART model is that it does not allow different tariff changes per tariff line (i.e. individual products), therefore we need to set all tariffs to a new base level.

\section{Model assumptions}

The SMART model requires three parameters as inputs: (1) import demand elasticity; (2) import substitution elasticity and (3) export supply elasticity. These elasticities are based on three important assumptions: (1) the assumption of import demand proposed by Armington (1969), (2) the two-stage optimization process of consumers, and (3) the assumption of infinite export supply elasticity.

Firstly, the smart model relies on the assumption that similar products from different countries are imperfect substitutes (the assumption of Armington (1969)). This assumption rules out the possibility that the entire import demand for apparels by the tariff eliminating country (EU members) would be met by the beneficiary country (Vietnam). In other words, EU countries would continue to depend on no beneficiary countries for meeting the rest of their import demand.

Secondly, the next assumption of SMART model is that buying decision of consumers follows a two-stage optimization process. At the first phase, customers' demand for the commodity will be changed by import demand elasticity. The value of import demand elasticity is primarily based on the calculations of the World Bank research team. At the second phase, the level of spending for this commodity depends on the relative price of national variety. The extent of the between-variety allocative response to a change in the relative price is determined by the import substitution elasticity (Amjadi et al., 2011). The default value of substitution elasticity imposed by SMART for all goods is set at 1.5, but for apparels, this average number seems to be less than reality (Baker et al., 2014). Calculating the accurate substitution elasticity value of a specific sector is very complicated and need micro data. Base parameters estimated on the studies of Stone (1979), Cline (1987), Suphachalasai (1989) and Yang (2007) calculated substitution elasticity of clothing and textile in many areas, including: US, Europe, China, Japan,... and with the textile substitution elasticity in EU market supposed to be equal to 4. Therefore, this research has adopted this value as the input of substitution elasticity to estimate the trade creation and diversion effects. 
Finally, the degree of responsiveness of the foreign exporter's supply to change in the export price is evaluated by the export supply elasticity. The SMART model in this study assumes infinite export supply elasticity (i.e. 99). This assumption allows the calculation of the effect of a tariff elimination while the price effect is remained at zero which means that all nations are faced with fixed world prices which implies small country case like the case of Vietnam (Lang, 2006; Veeramani \& Saini 2010; Othieno \& Shinyekwa, 2011; Amjadi et al. 2011).

\section{Model specification}

Depending on different objectives, scientists approach the partial equilibrium model in supplier or consumer side. Specifically, the trade creation and diversion effect is evaluated for both exporter and importer; while other indicators including revenue, welfare, import and export effects, are only calculated for importer. Therefore, in this study, we apply this model to Vietnam as an exporter of apparel products to EU, and estimate the impact of trade creation, diversion and total export to EU.

\section{Trade creation}

Trade creation in this model is estimated as the direct increase in imports due to a tariff reduction. The study adopted the below equation for trade creation which was derived by Laird and Yeats (1986):

$$
T C_{i j k}=M_{i j k} \cdot E_{x} \cdot \frac{d t_{i j k}}{\left(1+t_{i j k}\right)\left(1+\frac{E_{m}}{E_{x}}\right)}
$$

Trade diversion

Laird and Yates (1986) also calculated the trade diversion by using the elasticity of substitution. The diversion is the increase in imports from the FTAs partners' sources that replaces imports from efficiently producing sources in other countries.

$$
T D_{i j k}=\frac{M_{i j k}}{\sum M_{i j k}} \cdot \frac{\sum M_{i j k} \cdot \sum M_{i j K} \cdot E_{s} \cdot \frac{d\left(\frac{P_{i j k}}{P_{i j K}}\right)}{\frac{P_{i j k}}{P_{i j K}}}}{\sum M_{i j k}+\sum M_{i j K}+\sum M_{i j k} \cdot E_{S} \cdot \frac{d\left(\frac{P_{i j k}}{P_{i j K}}\right)}{\frac{P_{i j k}}{P_{i j K}}}}
$$

where,

TC: Trade creation

i: Subscript denoting commodity; in this case, it is apparels

$\mathrm{j}$ : Subscript denoting importing country; in this case, it is EU

k: Subscript denoting importing country; in this case, it is Vietnam

M: Imports

Ex: Elasticity of export supply

Em: Elasticity of import demand 
$\mathrm{t}$ : Tariff rate distortion

d: Prefix denoting change

Es: Elasticity of substitution

P: Price

K: Subscript denoting alternative foreign country.

\subsection{Input Data}

In this paper, all data of export and import values of T\&A were extracted from UN COMTRADE and Trade Map ${ }^{1}$ database and some trade flow and existing tariff level data contained in the interface already.

The impact of changes in tariffs compared to base year tariff in 2015 were simulated for the apparel products of Chapter 61 and 62 at HS 4, 6-digit level. The simulation eliminates duties on the HS classifications for apparel products, including 218 HS code at 6-digit level.

\subsection{Sensitive Analysis and Robustness test}

After estimating the effect of FTAs on trade by SMART model, sensitivity analysis and robustness test should be carried out to ensure that the simulation results are accurate and can be used to guide the policy making.

To conduct sensitivity analysis, according to the previous literature by Ratisai (2014) and Zgovu and Kweka (2008), the simulation is repeated under different scenario with applying differing substitution elasticities. This analysis is required before assessing the robustness of the results in the base case.

In the following sensitivity analysis, the elasticities are halved and then doubled to show how uncertain we are about modelling results (Huff et al., 1997).

Table 3.

Elasticities used in sensitivity analysis

\begin{tabular}{lcccc}
\hline Elasticity & Lower bound & Base case & Upper bound & Best case \\
\hline $\begin{array}{l}\text { Substitution } \\
\text { Elasticity }\end{array}$ & 2 & 4 & 6 & 8 \\
$\begin{array}{l}\text { Export supply } \\
\text { elasticity }\end{array}$ & 99 & 99 & 99 & 99 \\
\hline
\end{tabular}

As shown in the Table 3, the base case has the substitution elasticity of 4 . The other scenarios used in the robustness test are lower bound, upper bound and best case, (be equal to 2, 6 and 8 respectively). The export supply elasticities remained at 99 (as explained in the model assumption).

\footnotetext{
${ }^{1}$ UN Comtrade (https://comtrade.un.org/), Trade Map (https://www.trademap.org/)
} 


\section{Results And Discussion}

\subsection{Trade creation and trade diversion}

Trade creation, according to the results from the WITS-SMART model, shown in table 4 illustrates that the positive trade creation effect and total export change are consistent with economic theory.

Table 4.

Trade creation and trade diversion effects of Vietnam's apparel exports in EVFTA

\begin{tabular}{lc}
\hline Indicators & Effects (US\$ Million) \\
\hline Initial Exports Value in 2015 & $2,969.70$ \\
Exports Value in 2026 & $4,219.60$ \\
Total Export Change & $1,249.90$ \\
Trade Creation & 268.6 \\
Trade Diversion & 981.3 \\
Increase in exports (\%) & $42 \%$ \\
Trade creation/Total Export change (\%) & $21.50 \%$ \\
\hline
\end{tabular}

In general, with the subsequent reduction in the tariff line to $0 \%$ in 2026, Vietnam's apparel exports to EU will increase significantly by $42 \%$ compared to the base year, reaching US\$4.22 billion in the next 8 years. However, this skyrocketing increase is primarily attributed to the effect of trade diversion, whose value is nearly fourfold that of trade creation (US\$981.3 and 268.6 million respectively).

It is evident from Table 5 that the total trade effect has been rising over time with varied impacts across the product line of Vietnamese apparels. Table 5 presents a summary of the aggregate results obtained in the PE analysis at the level in 2-digit and 4-digit HS code.

In the Table 5, column (1) shows HS code of apparels; column (2) focuses on the value of exports to the EU in the base year; columns (3) and (4) shows the effects of trade creation and trade diversion; column (5) indicates the total trade effect and the impact in the EU market as percentage of exports is shown in column (6). The two final columns (7) and (8) show the duty rate before and after the implementation of the EVFTA. 
Table 5.

Trade creation and trade diversion effects of Vietnam's apparel exports in EVFTA at level 4-digit of HS. (US\$ Million)

\begin{tabular}{|c|c|c|c|c|c|c|c|}
\hline $\begin{array}{c}\text { HS } \\
\text { code }\end{array}$ & $\begin{array}{l}\text { Export } \\
\text { before } \\
(2015)\end{array}$ & $\begin{array}{c}\text { Trade } \\
\text { creation }\end{array}$ & $\begin{array}{c}\text { Trade } \\
\text { diversion }\end{array}$ & $\begin{array}{l}\text { Total } \\
\text { trade } \\
\text { effect }\end{array}$ & $\begin{array}{c}\% \\
\text { change }\end{array}$ & $\begin{array}{l}\text { Old Simple } \\
\text { Duty Rate } \\
(\%)(2015)\end{array}$ & $\begin{array}{c}\text { New Simple } \\
\text { Duty Rate (\%) } \\
(2026)\end{array}$ \\
\hline (1) & (2) & (3) & (4) & (5) & (6) & (7) & (8) \\
\hline 61 & 793.93 & 80.73 & 270.15 & 350.88 & $44.20 \%$ & 9.34 & 0 \\
\hline 6101 & 16.59 & 1.27 & 5.67 & 6.94 & $41.83 \%$ & 9.6 & 0 \\
\hline 6102 & 44.8 & 3.03 & 15.09 & 18.12 & $40.45 \%$ & 9.6 & 0 \\
\hline 6103 & 24.28 & 7.38 & 8.4 & 15.78 & $64.99 \%$ & 9.6 & 0 \\
\hline 6104 & 137.41 & 14.11 & 47.33 & 61.44 & $44.71 \%$ & 9.6 & 0 \\
\hline 6105 & 76.08 & 5.25 & 25.8 & 31.06 & $40.83 \%$ & 9.6 & 0 \\
\hline 6106 & 24.78 & 7.4 & 8.69 & 16.09 & $64.93 \%$ & 9.6 & 0 \\
\hline 6107 & 25.93 & 3.15 & 9.03 & 12.18 & $46.97 \%$ & 9.6 & 0 \\
\hline 6108 & 41 & 2.23 & 14.2 & 16.43 & $40.07 \%$ & 9.6 & 0 \\
\hline 6109 & 130.21 & 9.95 & 45.85 & 55.8 & $42.85 \%$ & 9.6 & 0 \\
\hline 6110 & 160.19 & 13.21 & 56.48 & 69.7 & $43.51 \%$ & 9.2 & 0 \\
\hline 6111 & 10.08 & 0.92 & 3.14 & 4.06 & $40.28 \%$ & 8.35 & 0 \\
\hline 6112 & 53.12 & 7.41 & 16.13 & 23.54 & $44.31 \%$ & 9.6 & 0 \\
\hline 6113 & 8.43 & 0.96 & 2.42 & 3.38 & $40.09 \%$ & 8 & 0 \\
\hline 6114 & 9.12 & 0.57 & 3.21 & 3.78 & $41.45 \%$ & 9.6 & 0 \\
\hline 6115 & 4.83 & 0.82 & 1.71 & 2.53 & $52.38 \%$ & 8 & 0 \\
\hline 6116 & 25.41 & 1.83 & 6.44 & 8.27 & $32.55 \%$ & 6.75 & 0 \\
\hline 6117 & 1.66 & 1.22 & 0.55 & 1.77 & $106.63 \%$ & 9.6 & 0 \\
\hline 62 & $2,175.76$ & 187.86 & 711.13 & 898.99 & $41.32 \%$ & 9.04 & 0 \\
\hline 6201 & 322.3 & 25.97 & 105.43 & 131.4 & $40.77 \%$ & 9.6 & 0 \\
\hline 6202 & 345.03 & 32.52 & 118.26 & 150.78 & $43.70 \%$ & 9.6 & 0 \\
\hline 6203 & 404.54 & 35.38 & 132.79 & 168.17 & $41.57 \%$ & 9.6 & 0 \\
\hline 6204 & 423.64 & 34.46 & 140.2 & 174.66 & $41.23 \%$ & 9.6 & 0 \\
\hline 6205 & 200.52 & 20.09 & 67.09 & 87.18 & $43.48 \%$ & 9.6 & 0 \\
\hline 6206 & 104.86 & 9.26 & 35.95 & 45.22 & $43.12 \%$ & 9.6 & 0 \\
\hline
\end{tabular}




\begin{tabular}{cccccccc}
\hline $\begin{array}{c}\text { HS } \\
\text { code }\end{array}$ & $\begin{array}{c}\text { Export } \\
\text { before } \\
(2015)\end{array}$ & $\begin{array}{c}\text { Trade } \\
\text { creation }\end{array}$ & $\begin{array}{c}\text { Trade } \\
\text { diversion }\end{array}$ & $\begin{array}{c}\text { Total } \\
\text { trade } \\
\text { effect }\end{array}$ & $\begin{array}{c}\% \\
\text { change }\end{array}$ & $\begin{array}{c}\text { Old Simple } \\
\text { Duty Rate } \\
(\%)(2015)\end{array}$ & $\begin{array}{c}\text { New Simple } \\
\text { Duty Rate }(\%) \\
(2026)\end{array}$ \\
\hline 6207 & 7 & 0.62 & 2.33 & 2.95 & $42.14 \%$ & 9.6 & 0 \\
6208 & 2.79 & 0.41 & 0.98 & 1.39 & $49.82 \%$ & 9.6 & 0 \\
6209 & 20.05 & 1.27 & 6.04 & 7.31 & $36.46 \%$ & 8.4 & 0 \\
6210 & 177.04 & 19.11 & 58.64 & 77.75 & $43.92 \%$ & 9.6 & 0 \\
6211 & 71.23 & 3.88 & 24.21 & 28.09 & $39.44 \%$ & 9.6 & 0 \\
6212 & 59.81 & 2.77 & 11.59 & 14.36 & $24.01 \%$ & 5.2 & 0 \\
6213 & 0.44 & 0.02 & 0.13 & 0.15 & $34.09 \%$ & 8 & 0 \\
6214 & 0.91 & 0.09 & 0.22 & 0.31 & $34.07 \%$ & 6.4 & 0 \\
6215 & 7.14 & 0.33 & 1.31 & 1.65 & $23.11 \%$ & 5 & 0 \\
6216 & 26.8 & 1.62 & 5.59 & 7.21 & $26.90 \%$ & 6 & 0 \\
6217 & 1.67 & 0.06 & 0.36 & 0.42 & $25.15 \%$ & 5 & 0 \\
Total & $5,939.40$ & 537.18 & $1,962.56$ & $2,499.74$ & $42.09 \%$ & & \\
\hline
\end{tabular}

Specifically, standing at 793.93 in 2015, Vietnamese HS 61 products exporting to the EU are expected to rise by US $\$ 350.88$ million in the 8-year period. Whereas, HS 62 exports will increase by US $\$ 898.99$ million, at the tax rate of $0 \%$ in 2026 . Nearly $50 \%$ of increases in Vietnam's apparel exporting to the EU would fall into the groups of HS 6104, 6109, 6110 and $6201,6202,6203,6204$.

Thus, it is clear that EVFTA will lead to trade diversion effect which dominates over trade creation effect when Vietnam's apparels are exported to the EU. The increase in Vietnam's exports to the EU due to the reduction of the Vietnam's apparels relative price is called trade diversion, which lead to lowers welfare of the EU because the low-cost production from the rest of the word is replaced by less efficient FTA member (Vietnam). The explanation for this could be that though Vietnam textile and apparel industry has witnessed significant development during the recent years, apparel manufacturing still belongs to imported materials. About 70 percent of Vietnam's textile and apparel production is via "processing trade" using imported materials and other inputs, predominantly from China. The results are inactive production and limited response ability. Moreover, the sector remains among the most labor- intensive industries while wages in Vietnam increase over the years.

While Vietnam will take a lot of gains when exporting to the EU, it is of interest to identify the non-EVFTA countries whose trade is being diverted to the EU as a result of the preferential tariff liberalization for Vietnamese apparels. Table 6 provides a list of top 10 non-EVFTA countries that account for the largest extent of trade diversion. 
Table 6.

List of top 10 non-EVFTA countries whose trade is being diverted to EU

\begin{tabular}{ccc}
\hline No & Nations & Value (Million US\$) \\
\hline 1 & China & -1015.69 \\
2 & Bangladesh & -212.03 \\
3 & Turkey & -171.83 \\
4 & India & -90.55 \\
5 & Morocco & -67.95 \\
6 & Cambodia & -52.09 \\
7 & Tunisia & -48.73 \\
8 & Indonesia & -43.50 \\
9 & Pakistan & -34.36 \\
10 & Sri Lanka & -31.74 \\
\hline
\end{tabular}

As expected, the list in Table 6 indicates the majority of nations affected by EVFTA are least developed or developing countries. The most affected countries are China, Bangladesh, Turkey and India. These also are the top apparels suppliers in the world.

\subsection{Sensitive Analysis and Robustness test}

As stated in Chapter 3, three different scenarios are repeated under the SMART model to check the robustness of the base case results.

The substitution elasticity value to 2 (the lower bound) reveals no change in trade creation effect from the base case. Moreover, the increase of the elasticities to 6 (upper bound) and 8 (best case) shows no changes in trade creation. As for the total export after EVFTA, the values are forecast to vary from US\$3,728.30 million (best case) to US\$5,207.40 million.

Table 7.

Sensitive Analysis and Robustness test using varying trade elasticities

\begin{tabular}{lcccc}
\hline Impact & Lower bound & Base case & Upper bound & Best case \\
\hline Trade creation & 268.6 & 268.6 & 268.6 & 268.6 \\
Export after & $3,728.30$ & $4,219.60$ & $4,712.50$ & $5,207.40$ \\
\hline
\end{tabular}

Using the results of robustness and sensitivity test in Table 7, the percentage changes of these scenarios are calculated as follows: 


$$
\% \text { change }=\frac{\text { Base case }- \text { Scenarios value }}{\text { Base case }} \times 100 \%
$$

\section{Table 8.}

Percentage changes from of scenario simulations from the base case

\begin{tabular}{lccc}
\hline Impact & Lower bound & Upper bound & Best case \\
\hline Trade creation & 0 & 0 & 0 \\
Export after & 11.6 & 11.6 & 23.2 \\
\hline
\end{tabular}

As can be noted, on the lower bound and upper bounds, the changes of trade creation fall within the $5 \%$ level of significance which means that the results from the base case are appropriate and can be used to propose the implications.

In relative terms, this future export change is profound; though not significant in absolute terms. The $11.6 \%$ change between the base case and lower case is considered minimal and the best case was considered robust.

\section{Conclusion and Implications}

Vietnam is considered as one of the dominant exporters of textile and apparel to major economies in the world, including the EU. As EVFTA comes into force in 2018 and by 2026, tariff rate of Vietnam's apparel to EU will be eliminated.

The study set out to find the potential effect of EVFTA using WITS-SMART model. Consequently, Vietnam's apparel exports to EU will increase significantly by $42 \%$ compared to the base year, reaching US $\$ 4.220$ billion in 2026. Specifically, nearly $50 \%$ of the increase would fall into the groups of HS 6104, 6109, 6110 and 6201, 6202, 6203, 6204. Despite the remarkable change in apparel export of Vietnam to EU, there is a very small attribution of trade creation in comparison to the size of trade diversion, with US\$268.6 million for the former and US\$981.3 million for the latter. Though Vietnam's apparels will get more gains than non-EVFTA members, it is not because of an effective allocation of resources. It is due to vast majority of increases in the EU imports from Vietnam attributable to duty elimination.

Therefore, some measures should be implemented to improve the competitiveness of Vietnam's apparels, to reduce the production price in order to bring advantages for both parties (Vietnam and EU), such as investing more in fiber, yarn and textile manufacturing, particularly for spinning and weaving, so the quality and quantity of apparel production is likely to increase. Moreover, Vietnamese government should develop supportive government policies, began to implement major infrastructure projects and introduced incentives for foreign producers to attract foreign direct investment.

Although Vietnam's apparel and textile industry is currently the world's third largest 
exporter, the country does not yet have international apparel brands that produce high value-added. Therefore, textile and apparel enterprises should have a strategy to build strong brands as well as develop brand values to increase competitiveness in the global market.

Besides that, regarding rules of origin, to benefit from EVFTA, after complying with certain administrative requirements, Vietnam's apparels must meet the demand for "fabrics originating". In the present, Vietnamese producers depend largely on fabric imported from China; however, with the EVFTA agreement coming into force, this trade could to shift to other producers such as South Korean fabrics.

\section{Limitation}

Regarding the research method used, SMART as a partial equilibrium model is static since it uses current data to make predictions without considering how other factors may change over time. Moreover, the results of PE models can be very sensitive to the values used for the elasticities, for which the empirical literature is still limited

\section{References}

Amjadi, A., Schuler, P., Kuwahara, H. and Quadros, S. (2011). WITS User's Manual. UNCTAD, UNSD, WTO, WB.

Armington, P. S. (1969). A Theory of Demand for Products Distinguished by Place of Production. Staff Papers, 16(1), 159-178.

Baker, P., Vanzetti, D. \& Pham, T. L. H. (2014) Đánh giá tác động dài hạn của hiệp định thương mại tự do Việt Nam-EU. MUTRAP EU-2 project.

Cassing, J., Trewin, R., Vanzetti, D., Truong, D.T, Nguyen, A. D. , Le, Q. L. \& Le, T. D. (2010). Impact assessment of Free Trade Agreement on Vietnam's Economy. Hanoi, Vietnam: MUTRAP.

Cline, W.R. (1987). The Future of World Trade in Textiles and Apparel. Institute for International Economics, Washington, DC.

Datta, A. and Kouliavtsev, M. (2009). NAFTA and the Realignment of Textile and Apparel Trade: Trade Creation or Trade Diversion? Review of International Economics, 17(1), 172186.

Freund, C. (2000). Different Paths to Free Trade: The Gains from Regionalism. Quarterly Journal of Economics, 115(4), 1317-1341.

GSO. (2016). Statistical book of Vietnam. General Statistics Office of Vietnam. Retrieved from http:/ / www.gso.gov.vn/ default.aspx?tabid=512\&idmid=\&ItemID=18531

Gurler, Z., Erdal, G., Erdal, H. \& Cicek, A. (2006). The Effects of Free Trade Agreement on Intra-industry Trade (A Case Study of Textile Sector in Turkey). Journal of Applied Sciences, 65, 1204-1208.

Huff, K. M., Hanslow, K., Hertel T. W. and Tsigas, M. E. (1997). GTAP behavioral 
parameters', in Hertel, T.W. (Eds.): Global Trade Analysis: Modeling and Applications. Cambridge University Press, Cambridge, 124-148.

ITC. (2016). International trade statistics. International Trade Centre. Retrieved from http:/ / www.intracen.org/itc/market-info-tools/trade-statistics/

Krueger, A. O. (1999). Trade Creation and Trade Diversion under NAFTA. NBER working paper 7429.

Laird, S. and Yeats, A. (1986) The UNCTAD trade policy simulation model. A note on the methodology, data and uses. UNCTAD discussion paper, 19. Retrieved from http://vi.unctad.org/tda/background/Partial Equilibrium Models SMART/ SMART.pdf

Lang, R. (2006). A partial-equilibrium analysis of the impact of the ECOWAS-EU. Economic Partnership Agreement United Nations Economic Commission for Africa.

Levy, P. (1997). A Political-Economic Analysis of Free-Trade Agreements. American Economic Review, 87, 506-519.

Mikic, M. (2005). Introduction to trade research II: Trade data and statistics. ARTNeT Capacity Building Workshop on Trade Research.

MOIT (2016). Overview of EVFTA agreement content. Ministry of Industry and Trade. Retrieved from http://www.moit.gov.vn/web/guest/tin-chi-tiet/-/chi-tiet/gioi-thieuve-du-thao-hiep-đinh-evfta-106576-22.html

Othieno, J. and Shinyekwa, M. (2011). Trade, Revenue and Welfare Effects of the East African Community Customs Union Principle of Asymmetry on Uganda: An Application of WITS-SMART Simulation Model. Economic Policy Research Centre, Research Series No. 79.

Platzer, M. D. (2012). U.S. Textile Manufacturing and the Trans-Pacific Partnership Negotiations. DC: Congressional Research Service.

Ratisai, C. (2014). An Assessment of the Impact of Zimbabwe Joining SACU using the WITSSMART model. A dissertation submitted in partial fulfilment of the requirements of the Master of Science Degree in Economics.

Sayres, N. J. (2002). The Vietnam-U.S. Textile Agreement Debate: Trade Patterns, Interests, and Labor Rights. Washington DC: Congressional Research Service. Online. Retrieved from http://www.usvtc.org/info/wb/CRS-Textile\%20Agreement\%20Jun02.pdf

Schiff, M., \& Winters, L. A. (2003). Regional Integration and Development. The World Bank.

Stone, A. J. (1979). Price Elasticities of Demand for Imports and Exports: Industry Estimates for the US, EEC and Japan. Review of Economics and Statistics, 61(2), 306-312.

Suphachalasai, S. (1989). The Effect of the Government Intervention and the Multifibre Arrangement on the Thai Clothing and Textiles Industry. Ph.D. dissertation, Australian National University, Canberra.

Tsang, W. Y. and Au, K. F. (2007). Textile and clothing exports of selected South and 
Southeast Asian countries: A challenge to NAFTA trading. Journal of Fashion Marketing and Management: An International Journal, 12(4), 565-578.

Veeramani, C. and Saini, G. K. (2010). Impact of ASEAN-India FTA on India's Plantation Commodities: A Simulation Analysis. Indira Gandhi Institute of Development Research, Mumbai Working Papers, 83-92.

Viner, J. (1950). The Customs Union Issue. New York: Carnegie Endowment for International Peace.

VITAS. (2016). Economy - Textile News. Vietnam Textile and Apparel Association. Retrieved from http://www.vietnamtextile.org.vn/images/upload/bantinthang/ Ban_tin_Tet_2016-upweb.pdf

Vu, H. T. (2016). Assessing potential impacts of the EVFTA on Vietnam's pharmaceutical imports from the EU: an application of SMART analysis. Springer Plus. 5(1), 1503. Retrieved from http://springerplus.springeropen.com/articles/10.1186/s40064-0163200-7

WCO. (2012). HS Nomenclature 2012 Edition. The World Customs Organization. Retrieved from: http:/ /www.wcoomd.org/en/faq/ /link.aspx?_id= 3F9BB5F791484D45810FE0A5B9782E4C\&_z=z

WTO. (2016). World Trade Statistical Review. World Trade Organization, 33. Retrieved from https://www.wto.org/english/res_e/statis_e/wts2016_e/wts2016_e.pdf

Vietnamese WTO Center. (2017). EU-Vietnam Free Trade Agreement: Agreed text as of January 2016. Vietnam Chamber of Commerce and Industry. Retrieved from http:/ / www.trungtamwto.vn/fta/199-viet-nam---eu-evfta/1

Yang, Y. (2007). The impact of MFA phasing out on world clothing and textile markets. The Journal of Development Studies, 30(4), 892-915.

Zgovu, E. K., \& Kweka, J. P. (2008). Empirical Analysis of Tariff Line-Level Trade, Tariff Revenue and Welfare Effects of Reciprocity under an economic Partnership Agreement with the EU: Evidence from Malawi and Tanzania. AERC Research Paper 184. African Economic Research Consortium, Nairobi. 


\section{Appendix A}

Description of Apparel's HS code

\begin{tabular}{|c|c|}
\hline HS code & Description \\
\hline 61 & $\begin{array}{l}\text { Articles of apparel and clothing } \\
\text { accessories, knitted or crocheted }\end{array}$ \\
\hline 6101 & $\begin{array}{l}\text { Men's or boys' overcoats, car coats, } \\
\text { capes, cloaks, anoraks (including ski } \\
\text { jackets), windcheaters, wind jackets and } \\
\text { similar articles, knitted or crocheted, } \\
\text { other than those of heading } 6103\end{array}$ \\
\hline 610120 & - Of cotton \\
\hline 610130 & - Of man-made fibers \\
\hline 610190 & - Of other textile materials \\
\hline 6102 & $\begin{array}{l}\text { Women's or girls' overcoats, car coats, } \\
\text { capes, cloaks, anoraks (including ski } \\
\text { jackets), windcheaters, wind-jackets and } \\
\text { similar articles, knitted or crocheted, } \\
\text { other than those of heading } 6104\end{array}$ \\
\hline 610210 & - Of wool or fine animal hair \\
\hline 610220 & - Of cotton \\
\hline 610230 & - Of man-made fibers \\
\hline 610290 & - Of other textile materials \\
\hline 6103 & $\begin{array}{l}\text { Men's or boys' suits, ensembles, jackets, } \\
\text { blazers, trousers, bib and brace overalls, } \\
\text { breeches and shorts (other than } \\
\text { swimwear), knitted or crocheted }\end{array}$ \\
\hline \multirow[t]{2}{*}{610310} & - Suits \\
\hline & - Ensembles \\
\hline 610322 & -- Of cotton \\
\hline 610323 & -- Of synthetic fibers \\
\hline \multirow[t]{2}{*}{610329} & -- Of other textile materials \\
\hline & - Jackets and blazers \\
\hline 610331 & -- Of wool or fine animal hair \\
\hline 610332 & -- Of cotton \\
\hline \multirow[t]{2}{*}{610333} & -- Of synthetic fibers \\
\hline & -- Of other textile materials \\
\hline 610339 & - Trousers, bib and brace overalls, \\
\hline
\end{tabular}

\begin{tabular}{|c|c|}
\hline & breeches and shorts \\
\hline 610341 & -- Of wool or fine animal hair \\
\hline 610342 & -- Of cotton \\
\hline 610343 & -- Of synthetic fibers \\
\hline 610349 & -- Of other textile materials \\
\hline \multirow[t]{2}{*}{6104} & $\begin{array}{l}\text { Women's or girls' suits, ensembles, } \\
\text { jackets, blazers, dresses, skirts, divided } \\
\text { skirts, trousers, bib and brace overalls, } \\
\text { breeches and shorts (other than } \\
\text { swimwear), knitted or crocheted }\end{array}$ \\
\hline & - Suits \\
\hline 610413 & -- Of synthetic fibers \\
\hline \multirow[t]{2}{*}{610419} & -- Of other textile materials \\
\hline & - Ensembles \\
\hline 610422 & -- Of cotton \\
\hline 610423 & -- Of synthetic fibers \\
\hline \multirow[t]{2}{*}{610429} & -- Of other textile materials \\
\hline & - Jackets and blazers \\
\hline 610431 & -- Of wool or fine animal hair \\
\hline 610432 & -- Of cotton \\
\hline 610433 & -- Of synthetic fibers \\
\hline \multirow[t]{2}{*}{610439} & -- Of other textile materials \\
\hline & - Dresses \\
\hline 610441 & -- Of wool or fine animal hair \\
\hline 610442 & -- Of cotton \\
\hline 610443 & -- Of synthetic fibers \\
\hline 610444 & -- Of artificial fibers \\
\hline \multirow[t]{2}{*}{610449} & -- Of other textile materials \\
\hline & - Skirts and divided skirts \\
\hline 610451 & -- Of wool or fine animal hair \\
\hline 610452 & -- Of cotton \\
\hline 610453 & -- Of synthetic fibers \\
\hline \multirow[t]{2}{*}{610459} & -- Of other textile materials \\
\hline & $\begin{array}{l}\text { - Trousers, bib and brace overalls, } \\
\text { breeches and shorts }\end{array}$ \\
\hline
\end{tabular}




\begin{tabular}{|c|c|}
\hline 610461 & -- Of wool or fine animal hair \\
\hline 610462 & -- Of cotton \\
\hline 610463 & -- Of synthetic fibers \\
\hline 610469 & -- Of other textile materials \\
\hline 6105 & $\begin{array}{l}\text { Men's or boys' shirts, knitted or } \\
\text { crocheted }\end{array}$ \\
\hline 610510 & - Of cotton \\
\hline 610520 & - Of man-made fibers \\
\hline 610590 & - Of other textile materials \\
\hline 6106 & $\begin{array}{l}\text { Women's or girls' blouses, shirts and } \\
\text { shirt-blouses, knitted or crocheted }\end{array}$ \\
\hline 610610 & - Of cotton \\
\hline 610620 & - Of man-made fibers \\
\hline 610690 & - Of other textile materials \\
\hline \multirow[t]{2}{*}{6107} & $\begin{array}{l}\text { Men's or boys' underpants, briefs, } \\
\text { nightshirts, pyjamas, bathrobes, } \\
\text { dressing gowns and similar articles, } \\
\text { knitted or crocheted }\end{array}$ \\
\hline & - Underpants and briefs \\
\hline 610711 & -- Of cotton \\
\hline 610712 & -- Of man-made fibres \\
\hline \multirow[t]{2}{*}{610719} & -- Of other textile materials \\
\hline & - Nightshirts and pyjamas \\
\hline 610721 & -- Of cotton \\
\hline 610722 & -- Of man-made fibres \\
\hline \multirow[t]{2}{*}{610729} & -- Of other textile materials \\
\hline & - Other \\
\hline 610791 & -- Of cotton \\
\hline 610799 & -- Of other textile materials \\
\hline \multirow[t]{2}{*}{6108} & $\begin{array}{l}\text { Women's or girls' slips, petticoats, } \\
\text { briefs, panties, nightdresses, pyjamas, } \\
\text { négligés, bathrobes, dressing gowns } \\
\text { and similar articles, knitted or crocheted }\end{array}$ \\
\hline & - Slips and petticoats \\
\hline 610811 & -- Of man-made fibres \\
\hline 610819 & -- Of other textile materials \\
\hline
\end{tabular}

\begin{tabular}{|c|c|}
\hline & - Briefs and panties \\
\hline 610821 & -- Of cotton \\
\hline 610822 & -- Of man-made fibres \\
\hline \multirow[t]{2}{*}{610829} & -- Of other textile materials \\
\hline & - Nightdresses and pyjamas \\
\hline 610831 & -- Of cotton \\
\hline 610832 & -- Of man-made fibres \\
\hline \multirow[t]{2}{*}{610839} & -- Of other textile materials \\
\hline & - Other \\
\hline 610891 & -- Of cotton \\
\hline 610892 & -- Of man-made fibres \\
\hline 610899 & -- Of other textile materials \\
\hline 6109 & $\begin{array}{l}\text { T-shirts, singlets and other vests, } \\
\text { knitted or crocheted }\end{array}$ \\
\hline 610910 & - Of cotton \\
\hline 610990 & - Of other textile materials \\
\hline \multirow[t]{2}{*}{6110} & $\begin{array}{l}\text { Jerseys, pullovers, cardigans, waistcoats } \\
\text { and similar articles, knitted or crocheted }\end{array}$ \\
\hline & - Of wool or fine animal hair \\
\hline 611011 & -- Of wool \\
\hline 611012 & -- Of Kashmir (cashmere) goats \\
\hline 611019 & -- Other \\
\hline 611020 & - Of cotton \\
\hline 611030 & - Of man-made fibres \\
\hline 611090 & - Of other textile materials \\
\hline 6111 & $\begin{array}{l}\text { Babies' garments and clothing } \\
\text { accessories, knitted or crocheted }\end{array}$ \\
\hline 611120 & - Of cotton \\
\hline 611130 & - Of synthetic fibers \\
\hline 611190 & - Of other textile materials \\
\hline \multirow[t]{2}{*}{6112} & $\begin{array}{l}\text { Tracksuits, ski suits and swimwear, } \\
\text { knitted or crocheted }\end{array}$ \\
\hline & - Tracksuits \\
\hline 611211 & -- Of cotton \\
\hline
\end{tabular}




\begin{tabular}{|c|c|}
\hline 611212 & -- Of synthetic fibers \\
\hline 611219 & -- Of other textile materials \\
\hline \multirow[t]{2}{*}{611220} & - Ski suits \\
\hline & - Men's or boys' swimwear \\
\hline 611231 & -- Of synthetic fibres \\
\hline \multirow[t]{2}{*}{611239} & -- Of other textile materials \\
\hline & - Women's or girls' swimwear \\
\hline 611241 & -- Of synthetic fibres \\
\hline 611249 & -- Of other textile materials \\
\hline 611300 & $\begin{array}{l}\text { Garments, made up of knitted or } \\
\text { crocheted fabric of heading 5903, } 5906 \\
\text { or } 5907\end{array}$ \\
\hline 6114 & Other garments, knitted or crocheted \\
\hline 611420 & - Of cotton \\
\hline 611430 & - Of man-made fibres \\
\hline 611490 & - Of other textile materials \\
\hline 6115 & $\begin{array}{l}\text { Pantyhose, tights, stockings, socks and } \\
\text { other hosiery, including graduated } \\
\text { compression hosiery (for example, } \\
\text { stockings for varicose veins) and } \\
\text { footwear without applied soles, knitted } \\
\text { or crocheted }\end{array}$ \\
\hline \multirow[t]{2}{*}{611510} & $\begin{array}{l}\text { - Graduated compression hosiery (for } \\
\text { example, stockings for varicose veins) }\end{array}$ \\
\hline & - Other pantyhose and tights \\
\hline 611521 & $\begin{array}{l}\text {-- Of synthetic fibres, measuring per } \\
\text { single yarn less than } 67 \text { decitex }\end{array}$ \\
\hline 611522 & $\begin{array}{l}\text {-- Of synthetic fibres, measuring per } \\
\text { single yarn } 67 \text { decitex or more }\end{array}$ \\
\hline 611529 & -- Of other textile materials \\
\hline \multirow[t]{2}{*}{611530} & $\begin{array}{l}\text { - Other women's full-length or knee- } \\
\text { length hosiery, measuring per single } \\
\text { yarn less than } 67 \text { decitex }\end{array}$ \\
\hline & - Other \\
\hline 611594 & -- Of wool or fine animal hair \\
\hline 611595 & -- Of cotton \\
\hline 611596 & -- Of synthetic fibers \\
\hline
\end{tabular}

\begin{tabular}{|c|c|}
\hline 611599 & -- Of other textile materials \\
\hline 6116 & $\begin{array}{l}\text { Gloves, mittens and mitts, knitted or } \\
\text { crocheted }\end{array}$ \\
\hline \multirow[t]{2}{*}{611610} & $\begin{array}{l}\text { - Impregnated, coated or covered with } \\
\text { plastics or rubber }\end{array}$ \\
\hline & - Other \\
\hline 611691 & -- Of wool or fine animal hair \\
\hline 611692 & -- Of cotton \\
\hline 611693 & -- Of synthetic fibers \\
\hline 611699 & -- Of other textile materials \\
\hline 6117 & $\begin{array}{l}\text { Other made-up clothing accessories, } \\
\text { knitted or crocheted; knitted or } \\
\text { crocheted parts of garments or of } \\
\text { clothing accessories }\end{array}$ \\
\hline 611710 & $\begin{array}{l}\text { - Shawls, scarves, mufflers, mantillas, } \\
\text { veils and the like }\end{array}$ \\
\hline 611780 & - Other accessories \\
\hline 611790 & - Parts \\
\hline 62 & $\begin{array}{l}\text { ARTICLES OF APPAREL AND } \\
\text { CLOTHING ACCESSORIES, NOT } \\
\text { KNITTED OR CROCHETED }\end{array}$ \\
\hline \multirow[t]{2}{*}{6201} & $\begin{array}{l}\text { Men's or boys' overcoats, car coats, } \\
\text { capes, cloaks, anoraks (including ski } \\
\text { jackets), windcheaters, wind jackets and } \\
\text { similar articles, other than those of } \\
\text { heading } 6203\end{array}$ \\
\hline & $\begin{array}{l}\text { - Overcoats, raincoats, car coats, capes, } \\
\text { cloaks and similar articles }\end{array}$ \\
\hline 620111 & -- Of wool or fine animal hair \\
\hline 620112 & -- Of cotton \\
\hline 620113 & -- Of man-made fibers \\
\hline \multirow[t]{2}{*}{620119} & -- Of other textile materials \\
\hline & - Other \\
\hline 620191 & -- Of wool or fine animal hair \\
\hline 620192 & -- Of cotton \\
\hline 620193 & -- Of man-made fibres \\
\hline 620199 & -- Of other textile materials \\
\hline
\end{tabular}




\begin{tabular}{|c|c|}
\hline 6202 & $\begin{array}{l}\text { Women's or girls' overcoats, car coats, } \\
\text { capes, cloaks, anoraks (including ski } \\
\text { jackets), windcheaters, wind-jackets and } \\
\text { similar articles, other than those of } \\
\text { heading } 6204\end{array}$ \\
\hline & $\begin{array}{l}\text { - Overcoats, raincoats, car coats, capes, } \\
\text { cloaks and similar articles }\end{array}$ \\
\hline 620211 & -- Of wool or fine animal hair \\
\hline 620212 & -- Of cotton \\
\hline 620213 & -- Of man-made fibres \\
\hline \multirow[t]{2}{*}{620219} & -- Of other textile materials \\
\hline & - Other \\
\hline 620291 & -- Of wool or fine animal hair \\
\hline 620292 & -- Of cotton \\
\hline 620293 & -- Of man-made fibers \\
\hline 620299 & -- Of other textile materials \\
\hline \multirow[t]{2}{*}{6203} & $\begin{array}{l}\text { Men's or boys' suits, ensembles, jackets, } \\
\text { blazers, trousers, bib and brace overalls, } \\
\text { breeches and shorts (other than } \\
\text { swimwear) }\end{array}$ \\
\hline & - Suits \\
\hline 620311 & -- Of wool or fine animal hair \\
\hline 620312 & -- Of synthetic fibers \\
\hline \multirow[t]{2}{*}{620319} & -- Of other textile materials \\
\hline & - Ensembles \\
\hline 620322 & -- Of cotton \\
\hline 620323 & -- Of synthetic fibers \\
\hline \multirow[t]{2}{*}{620329} & -- Of other textile materials \\
\hline & - Jackets and blazers \\
\hline 620331 & -- Of wool or fine animal hair \\
\hline 620332 & -- Of cotton \\
\hline 620333 & -- Of synthetic fibers \\
\hline \multirow[t]{2}{*}{620339} & -- Of other textile materials \\
\hline & $\begin{array}{l}\text { - Trousers, bib and brace overalls, } \\
\text { breeches and shorts }\end{array}$ \\
\hline 620341 & -- Of wool or fine animal hair \\
\hline
\end{tabular}

\begin{tabular}{|c|c|}
\hline 620342 & -- Of cotton \\
\hline 620343 & -- Of synthetic fibers \\
\hline 620349 & --- Of artificial fibers \\
\hline \multirow[t]{2}{*}{6204} & $\begin{array}{l}\text { Women's or girls' suits, ensembles, } \\
\text { jackets, blazers, dresses, skirts, divided } \\
\text { skirts, trousers, bib and brace overalls, } \\
\text { breeches and shorts (other than } \\
\text { swimwear) }\end{array}$ \\
\hline & - Suits \\
\hline 620411 & -- Of wool or fine animal hair \\
\hline 620412 & -- Of cotton \\
\hline 620413 & -- Of synthetic fibers \\
\hline \multirow[t]{2}{*}{620419} & -- Of other textile materials \\
\hline & - Ensembles \\
\hline 620421 & -- Of wool or fine animal hair \\
\hline 620422 & -- Of cotton \\
\hline 620423 & -- Of synthetic fibers \\
\hline 620429 & -- Of other textile materials \\
\hline 620431 & -- Of wool or fine animal hair \\
\hline 620432 & -- Of cotton \\
\hline 620433 & -- Of synthetic fibers \\
\hline \multirow[t]{2}{*}{620439} & -- Of other textile materials \\
\hline & - Dresses \\
\hline 620441 & -- Of wool or fine animal hair \\
\hline 620442 & -- Of cotton \\
\hline 620443 & -- Of synthetic fibers \\
\hline 620444 & -- Of artificial fibers \\
\hline \multirow[t]{2}{*}{620449} & -- Of other textile materials \\
\hline & - Skirts and divided skirts \\
\hline 620451 & -- Of wool or fine animal hair \\
\hline 620452 & -- Of cotton \\
\hline 620453 & -- Of synthetic fibers \\
\hline \multirow[t]{2}{*}{620459} & -- Of other textile materials \\
\hline & $\begin{array}{l}\text { - Trousers, bib and brace overalls, } \\
\text { breeches and shorts }\end{array}$ \\
\hline
\end{tabular}




\begin{tabular}{|c|c|}
\hline 620461 & -- Of wool or fine animal hair \\
\hline 620462 & -- Of cotton \\
\hline 620463 & -- Of synthetic fibers \\
\hline 620469 & -- Of other textile materials \\
\hline 6205 & Men's or boys' shirts \\
\hline 620520 & - Of cotton \\
\hline 620530 & - Of man-made fibers \\
\hline 620590 & - Of other textile materials \\
\hline 6206 & $\begin{array}{l}\text { Women's or girls' blouses, shirts and } \\
\text { shirt-blouses }\end{array}$ \\
\hline 620610 & - Of silk or silk waste \\
\hline 620620 & - Of wool or fine animal hair \\
\hline 620630 & - Of cotton \\
\hline 620640 & - Of man-made fibers \\
\hline 620690 & - Of other textile materials \\
\hline \multirow[t]{2}{*}{6207} & $\begin{array}{l}\text { Men's or boys' singlets and other vests, } \\
\text { underpants, briefs, nightshirts, pyjamas, } \\
\text { bathrobes, dressing gowns and similar } \\
\text { articles }\end{array}$ \\
\hline & - Underpants and briefs \\
\hline 620711 & -- Of cotton \\
\hline \multirow[t]{2}{*}{620719} & -- Of other textile materials \\
\hline & - Nightshirts and pyjamas \\
\hline 620721 & -- Of cotton \\
\hline 620722 & -- Of man-made fibers \\
\hline \multirow[t]{2}{*}{620729} & -- Of other textile materials \\
\hline & - other \\
\hline 620791 & -- Of cotton \\
\hline 620799 & -- Of other textile materials \\
\hline \multirow[t]{2}{*}{6208} & $\begin{array}{l}\text { Women's or girls' singlets and other } \\
\text { vests, slips, petticoats, briefs, panties, } \\
\text { nightdresses, pyjamas, negligee, } \\
\text { bathrobes, dressing gowns and similar } \\
\text { articles }\end{array}$ \\
\hline & - Slips and petticoats \\
\hline 620811 & -- Of man-made fibers \\
\hline
\end{tabular}

\begin{tabular}{|c|c|}
\hline 620819 & -- Of other textile materials \\
\hline & - Nightdresses and pyjamas \\
\hline 620821 & -- Of cotton \\
\hline 620822 & -- Of man-made fibers \\
\hline \multirow[t]{2}{*}{620829} & -- Of other textile materials \\
\hline & - Other \\
\hline 620891 & -- Of cotton \\
\hline 620892 & -- Of man-made fibers \\
\hline 620899 & -- Of other textile materials \\
\hline 6209 & $\begin{array}{l}\text { Babies' garments and clothing } \\
\text { accessories }\end{array}$ \\
\hline 620920 & - Of cotton \\
\hline 620930 & - Of synthetic fibers \\
\hline 620990 & - Of other textile materials \\
\hline 6210 & $\begin{array}{l}\text { Garments, made up of fabrics of } \\
\text { heading } 5602,5603,5903,5906 \text { or } 5907\end{array}$ \\
\hline 621010 & - Of fabrics of heading 5602 or 5603 \\
\hline 621020 & $\begin{array}{l}\text {-- Other garments, of the type described } \\
\text { in subheadings } 620111 \text { to } 620119\end{array}$ \\
\hline 621030 & $\begin{array}{l}\text { - Other garments, of the type described } \\
\text { in subheadings } 620211 \text { to } 620219\end{array}$ \\
\hline 621040 & - Other men's or boys' garments \\
\hline 621050 & - Other women's or girls' garments \\
\hline \multirow[t]{2}{*}{6211} & $\begin{array}{l}\text { Tracksuits, ski suits and swimwear; } \\
\text { other garments }\end{array}$ \\
\hline & - Swimwear \\
\hline 621111 & -- Men's or boys' \\
\hline 621112 & -- Women's or girls' \\
\hline \multirow[t]{2}{*}{621120} & - Ski suits \\
\hline & - Other garments, men's or boys' \\
\hline 621132 & -- Of cotton \\
\hline 621133 & -- Of man-made fibers \\
\hline \multirow[t]{2}{*}{621139} & -- Of other textile materials \\
\hline & - Other garments, women's or girls' \\
\hline 621142 & -- Of cotton \\
\hline
\end{tabular}




\begin{tabular}{|l|l|}
621143 & -- Of man-made fibers \\
\hline 621149 & -- Of other textile materials \\
\hline 6212 & $\begin{array}{l}\text { Brassieres, girdles, corsets, braces, } \\
\text { suspenders, garters and similar articles } \\
\text { and parts thereof, whether or not } \\
\text { knitted or crocheted }\end{array}$ \\
\hline 621210 & - Brassieres \\
\hline 621220 & - Girdles and panty girdles \\
\hline 621230 & - Corselettes \\
\hline 621290 & - Other \\
\hline 6213 & Handkerchiefs \\
\hline 621320 & - Of cotton \\
\hline 621390 & - Of other textile materials \\
\hline 6214 & $\begin{array}{l}\text { Shawls, scarves, mufflers, mantillas, } \\
\text { veils and the like }\end{array}$ \\
\hline 621410 & - Of silk or silk waste \\
\hline
\end{tabular}

\begin{tabular}{|l|l|}
\hline 621420 & - Of wool or fine animal hair \\
\hline 621430 & - Of synthetic fibers \\
\hline 621440 & - Of artificial fibers \\
\hline 621490 & - Of other textile materials \\
\hline 6215 & Ties, bow ties and cravats \\
\hline 621510 & - Of silk or silk waste \\
\hline 621520 & - Of man-made fibers \\
\hline 621590 & - Of other textile materials \\
\hline 621600 & Gloves, mittens and mitts \\
\hline 6217 & $\begin{array}{l}\text { Other made-up clothing accessories; } \\
\text { parts of garments or of clothing } \\
\text { accessories, other than those of heading } \\
6212\end{array}$ \\
\hline 621710 & - Accessories \\
\hline 621790 & \begin{tabular}{l} 
- Parts \\
\hline
\end{tabular} \\
\hline
\end{tabular}

Source: The World Customs Organization (WCO), 2012 